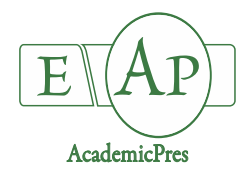

Khordadi Varamin J et al. (2020)

Notulae Botanicae Horti Agrobotanici Cluj-Napoca 48(4):2228-2243

DOI: $10.15835 /$ nbha48411852

Research Article

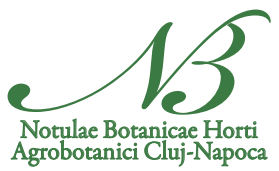

\title{
Foliar application of chitosan and nano-magnesium fertilizers influence on seed yield, oil content, photosynthetic pigments, antioxidant enzyme activities of sesame (Sesamum indicum L.) under water-limited conditions
}

\author{
Jaber KHORDADI VARAMIN ${ }^{1}$, Farzad FANOODI ${ }^{2 *}$, \\ Jafar MASOUD SINAKI ${ }^{2}$, Shahram REZVAN ${ }^{2}$, Ali DAMAVANDI ${ }^{2}$ \\ IDepartment of Agronomy, Islamic Azad University, Damghan Branch, Damghan, Iran; Jaber.khordadai@gmail.com \\ ${ }^{2}$ Department of Agriculture, Damghan Branch, Islamic Azad University, Damghan, Iran; farzad.fanoodi@yahoo.com \\ ("corresponding author);jmsinaki2020@gamil.com; shahram.rezvan@yahoo.com; ali.damavandi@yahoo.com
}

\begin{abstract}
Applying elicitors and nano-fertilizer has been recommended to enhance the growth and yield of secondary metabolites in herbs and medicinal plants under water-limited stress. However, less information is available on the effects of chitosan and nano-magnesium fertilizers on sesame seed yield, oil content, and physiological traits in the presence of nanomagnesium chelate (nano-Mg) under water-limited supply. In this regard, field experiments as a split-factorial experiment was performed based on randomized blocks in three replicates in Varamin city, south of Tehran, Iran, during 2015-2016 to evaluate the impact of chitosan and nano-Mgon physiological, seed, and oil traits of sesame. Irrigation cut-offbased on $\mathrm{BBCH}$ scale was considered as the main factor including normal irrigation $\left(\mathrm{I}_{1}\right)$, irrigation cut-off in $75\left(\mathrm{I}_{2}\right)$, and $65 \mathrm{BBCH}\left(\mathrm{I}_{3}\right)$ stages. Secondary factors as the subplot included 'Oltan' (C1) and 'Dashtestan-2' (C2) sesame cultivars, and foliar application of nano- $\mathrm{Mg}$ (application and non-application) and chitosan (control (CH1), foliar application of $4.8 \mathrm{gL}^{-1}$ in $65 \mathrm{BBCH}(\mathrm{CH} 2)$, and $6.4 \mathrm{~g} \mathrm{~L}^{-1}$ in $75 \mathrm{BBCH}$ stages $\left.(\mathrm{CH} 3)\right)$. Further, free proline content, total sugars, the activity of antioxidant enzymes including catalase (CAT, EC 1.11.1.6), peroxidase (POD, EC 1.11.1), and ascorbate peroxidase (APX, EC 1.11.1.11), photosynthetic pigments content, seed yield, and oil content were evaluated in the next stage. Based on the results, irrigation cut-off in $65 \mathrm{BBCH}$ stage (flowering) significantly increased free proline content, total sugars, and the activity of antioxidant enzymes, CAT, POD, and APX. However, chlorophyll a, b, and total contents, seed yield, oil percentage, and yield decreased under water stress. 'Dashtestan-2' cultivar had the highest seed yield and oil content, and more tolerant cultivar under waterlimited stress. Interestingly, the production of proline content and total sugars increased while the activity of antioxidant enzymes, CAT, POD, and APX decreased under application of nano-Mgand $\mathrm{CH} 2$, which influenced both sesame response and seed attributes. As a result, the production of some physiological traits in sesame cultivars may be regulated by adjusting the irrigating practices. Finally, the co-application of nano- $\mathrm{Mg}$ and $\mathrm{CH} 2$ increased the seed yield and oil content of sesame under limited water supply in the arid and semi-arid region.
\end{abstract}

Keywords: chlorophyll; catalase; drought stress; elicitors; free proline

Abbreviations: APX: ascorbate peroxidase; CAT: catalse; nano-Mg: nano-magnesium chelate; POD; peroxidase 


\section{Introduction}

Sesame (Sesamum indicum L.) is annual and self-pollinating, which belongs to Pedaliaceae family. In addition, it is regarded as one of the oldest oysters, which can be adapted to warm and semi-warm regions, known as the queen of oilseed plants. The seeds of this plant contain $44-58 \%$ oils, $18-25 \%$ proteins, and $13.5 \%$ $\sim$ carbohydrates. The proper quality of sesame including cholesterol level and the presence of some antioxidants such as Sameen, Samolin, and Samol play an important role in human health. On the other hand, it is considered as a tolerant plant to the drought stress (Roul et al., 2017).

Water-limited stress is the major abiotic stress mainly in the agricultural fields all over the world, which affects almost all agricultural crops and diminishes the productivity considerably. Two-thirds of food production in the world is obtained through agriculture in drought stress conditions while more than $45 \%$ of agricultural land is permanently under drought stress (Yanni et al., 2016). Therefore, sesame is a desirable plant for cultivation under drought stress conditions. In addition, most of the plant species respond to abiotic stress through molecular, biochemical and physiological modifications, and ultimately morphological adaptations (Taieb et al., 2016). Further, plants have evolved many different mechanisms to deal with the occurrence of water-limited conditions (Kebbas et al., 2018). The results of some research indicated that the drought stress generally results in destructing the chloroplasts, and decreasing chlorophyll content and the activity of enzymes in the Calvin cycle during the photosynthesis process (Anaya et al., 2018). In this regard, Mafakheri et al. (2010) reported a decrease in leaf chlorophyll content due to drought stress. According to Farouk and Amany (2012), the toleration of the plants to the drought stress is achieved by various methods such as closing the stomata, osmotic regulation, and accumulation of compatible solution materials. When plants are exposed to drought stress, and osmotic stress in many osmotic adjustment processes results in accumulating non-toxic soluble materials such as proline and sugar in the cell. Further, the dehydration leads to oxidative stress, a process in which reactive oxygen species (ROS) react with lipids, proteins, nucleic acids, and cellular enzymes, which results in cell death. ROS is regarded as the result of electron transfer in mitochondria, chloroplasts, and cytosols, leading to the formation of superoxide $\left(\mathrm{O}^{2-}\right)$, hydrogen peroxide $\left(\mathrm{H}_{2} \mathrm{O}_{2}\right)$, radical hydroxyl, and singlet oxygen. Further, the first defensive barrier against enzymatic and non-enzymatic antioxidants is the resistance toward ROS in plant cells. The first defence line against ROS to enzymatic and non-enzymatic antioxidants increases in plant cells. In this regard, the increased activity of antioxidant enzymes due to drought stress was reported by Murshed et al. (2013).

Water-limited stress leads to an imbalance in absorbing the nutrients from the soil and plant nutrition is very important in such a condition. Magnesium $(\mathrm{Mg})$ has been implicated as a common ingredient in several critical processes of physiology and biochemical activity in plants including the formation of ATP in chloroplasts, $\mathrm{CO}_{2}$ stabilization, protein synthesis, chlorophyll formation, pharyngeal development, and optical oxidation in leaves. Furthermore, it is important for Grana accumulation in chloroplasts (Ceppi et al., 2012). According to Senbayram et al. (2015), the deficiency of $\mathrm{Mg}^{2+}$ leads to plant damage, which is assumed that the availability of sufficient $\mathrm{Mg}$ is effective to achieve optimal performance in drought stress conditions. The use of $\mathrm{Mg}$ increases soluble sugars and protein in soybean. The deficiency of $\mathrm{Mg}^{2+}$ may cause oxidative stress inside plant cells. Under $\mathrm{Mg}$ deficiency condition, $\mathrm{CO}_{2}$ stabilization results in damaging the RUBP carboxylase by reducing the biosynthesis, which may lead to the production of ROS, damage to photosystem I and II, and a reduction in growth and yield of the plant. The results of some studies indicated a reduction in the concentration of soluble sugars and protein in soybean under Mg deficiency, a decrease in proline content, and an increase in the activity of catalase enzyme in rice (Chou et al., 2010).

Chitosan $\left(\mathrm{C}_{11} \mathrm{H}_{17} \mathrm{O}_{7} \mathrm{~N}_{2}\right)$ is a polyacetate polysaccharide, which is produced as a natural polymer from Alkaline $\mathrm{N}$-deacetylation of chitin and is regarded as the second most abundant polymer on earth, which is the cell wall of some fungi and insects, leading to the production of some algae (Solgi, 2018). Further, this material created from the compounds with the properties of opiatetrium which impose plant defence mechanisms 
against stress and improve plant growth. Some researchers believe that this substance can increase the activity of antioxidant enzymes and act as a neutralizing ROS (Sheikha and Al-Malki, 2011). Regarding the application of chitosan foliar, some studies reported an increase in chlorophyll content, catalase activity, soluble protein content, and soluble sugars and proline content (Pongprayoon et al., 2013; Sultana et al., 2017).

Nano-fertilizers include the nutrients with the size 30 to 40 nanometer and can carry nutrients properly due to their high surface. The use of nano-fertilizers to control the release of nutrients accurately can be considered as an effective step toward achieving sustainable and eco-friendly agriculture. Further, $\mathrm{Mg}$ is an important task for plants based on quantitative and qualitative, energy conservation, protein synthesis, structure stability, and sugar accumulation, as well as controlling $\mathrm{pH}$ in the cell and a cofactor for many enzymes (Blasco et al., 2015).

Assessing the role of nano-fertilizers and elicitor as a strategy is important for reducing the negative effects of drought stress on plants. In this regard, the present study aimed to evaluate the effect of magnesium nano-chelate and chitosan elicitor on the activity of antioxidant enzymes, photosynthetic pigments, seed yield, and oil content of sesame under water-limited stress in order to provide a suitable way for reducing drought stresses and achieving sustainable agriculture in arid and semi-arid regions.

\section{Materials and Methods}

\section{Plant material and growth condition}

A field experiment was conducted to investigate the effects of using chitosan and nano-Mg fertilizers on some physiological traits of two sesame cultivars ('Oltan' and 'Dashtestan-2') in the second cultivation during 2015-2016. The experiment was performed in a research farm in Varamin city, the South of Tehran Province, Iran $\left(35^{\circ} 30^{\prime}\right.$ latitudes and $51^{\circ} 73^{\prime}$ longitudes) (Figure 1). Climate and meteorological data during the experiment period was shown in Figure 2. The physical and chemical properties of soil were analysed by using the standard methods (Table 1).

Table 1. The physical and chemical properties of the experimental fields (2015 and 2016)

\begin{tabular}{|c|c|c|c|c|c|c|c|c|c|c|c|c|}
\hline Depth & $\mathrm{pH}$ & $\mathrm{EC}$ & $\mathrm{OC}$ & $\mathrm{TNV}$ & $\mathrm{N}$ & $\mathrm{P}$ & $\mathrm{K}$ & $\mathrm{Mg}$ & clay & silt & sand & Texture \\
\hline $\mathrm{cm}$ & - & $\mathrm{dS} \mathrm{m}^{-1}$ & $\%$ & $\%$ & $\%$ & $\mathrm{ppm}$ & $\mathrm{ppm}$ & $\mathrm{ppm}$ & $\%$ & $\%$ & $\%$ & - \\
\hline \multicolumn{10}{|c|}{2015} \\
\hline $0-30$ & 7.68 & 5.38 & 0.55 & 20.58 & 0.05 & 12 & 284.2 & 1.95 & 19 & 46 & 35 & loam \\
\hline \multicolumn{10}{|c|}{2016} \\
\hline $0-30$ & 7.61 & 4.96 & 0.56 & 20.46 & 0.04 & 13.5 & 245.3 & 1.71 & 20 & 44 & 36 & loam \\
\hline
\end{tabular}



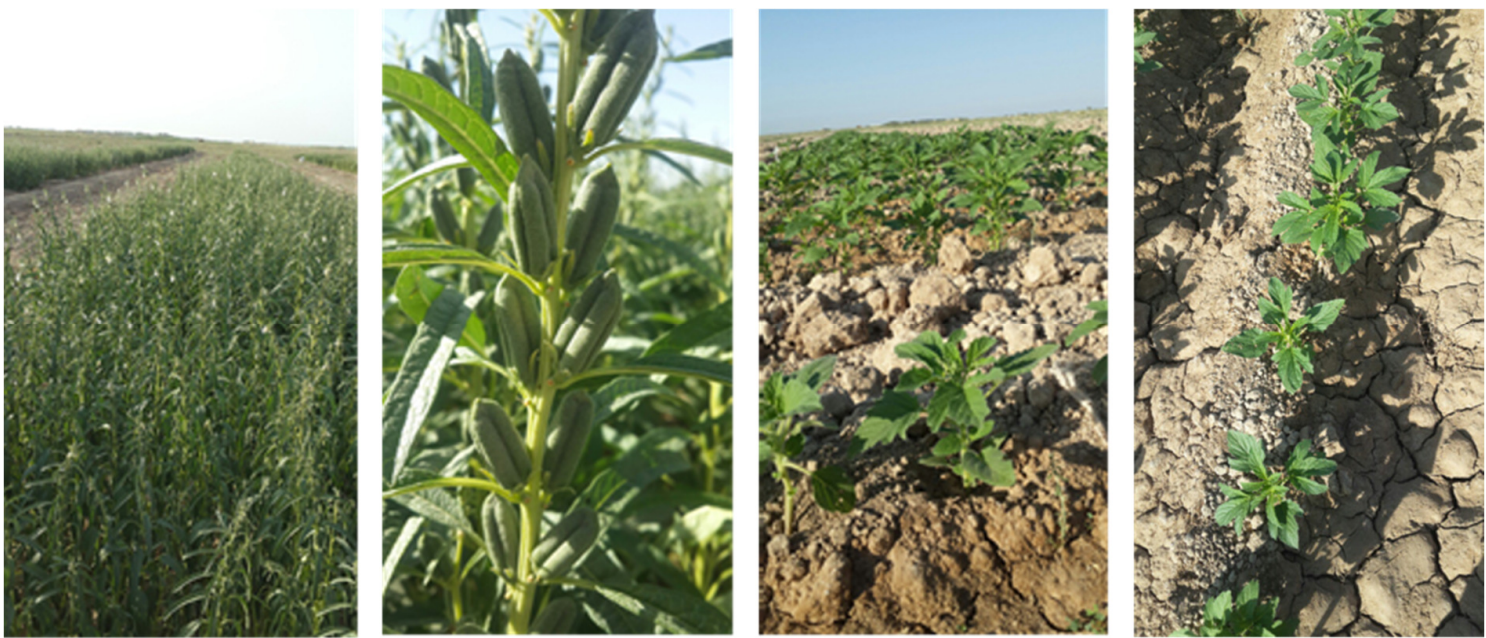

Figure 1. Sesame seedlings and plants in the research field during the experiments

2016 Average temperature (0 C)

2017 Average temperature (0 C)

$\multimap 2016$ Total monthly precipitation $(\mathrm{mm}) \multimap 2017$ Total monthly precipitation $(\mathrm{mm})$

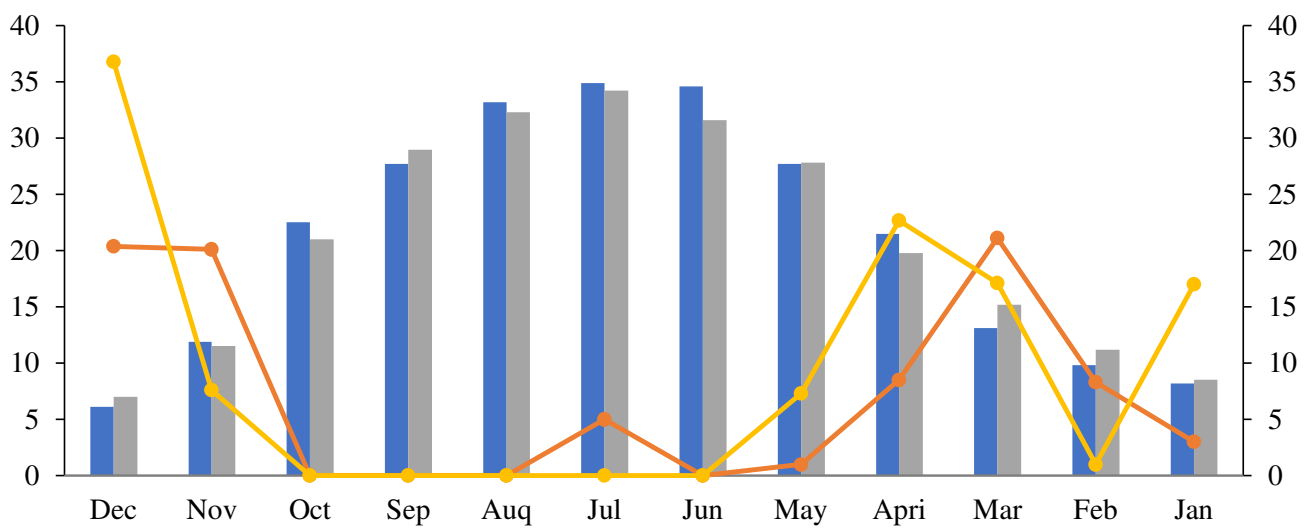

Figure 2. Climate and meteorological data during the experiment period

\section{Experimental design}

A factorial split plot experiment was conducted based on a completely randomized block design (CRBD) with three replicates by using irrigation levels including control (normal irrigation: $I_{1}$ ), irrigation up to seed ripening $\left(75 \mathrm{BBCH}=\right.$ mild stress: $\left.\mathrm{I}_{2}\right)$, and irrigation up to flowering $\left(65 \mathrm{BBCH}=\right.$ severe stress: $\left.\mathrm{I}_{3}\right)$ as the main plots. The foliar application of nano- $\mathrm{Mg}$ at 0 and $2 \mathrm{gL}^{-1}$ concentrations, chitosan at $0(\mathrm{CH} 1), 4.8(\mathrm{CH} 2)$, and 6.4 (CH3) $\mathrm{g} \mathrm{L}^{-1}$ concentrations, as well as two sesame cultivars including 'Oltan' (C1) and 'Dashtestan-2' (C2) were used as the subplots.

\section{Field practices}

The field was prepared by using mouldboard and smoothed using disk, and the plots $(3 \times 3 \mathrm{~m})$ were established during June 2015 and 2016. The seeds were planted in the depth of 1-1.5 cm in the plots, which were $1 \mathrm{~m}$ apart including 6 rows ( $50 \mathrm{~cm}$ apart). The field was fertilized according to soil testing using urea (150 $\left.\mathrm{kg} \mathrm{ha}^{-1}\right)$ and $100 \mathrm{~kg}$ of $\mathrm{P}_{2} \mathrm{O}_{5}$ per ha in the form of triple superphosphate. The plots were irrigated on a ridge planting and the irrigation time was determined by using Class A evaporation pan (in $70 \mathrm{~mm}$ evapotranspiration). Then, the irrigation treatments such as irrigation up to $50 \%$ flowering and seed ripening 
were performed after foliar application of nutrients. According to the treatments, the irrigation frequency for control, mild, and severe stresses were 8,7 , and 5 times, respectively. The foliar application of nano-Mg $(2 \mathrm{~g} \mathrm{~L}$ $\left.{ }^{1}\right)$ and chitosan $\left(4.8 \mathrm{~g} \mathrm{~L}^{-1}\right)$ was conducted in $65 \mathrm{BBCH}$ stage and $6.4 \mathrm{~g} \mathrm{~L}^{-1}$ chitosan was performed in $75 \mathrm{BBCH}$ stage. Based on the available documents, $75 \mathrm{BBCH}$ is equivalent to seed about $50 \%$ of the final size and 65 $\mathrm{BBCH}$ equals to $50 \%$ of flower open. As for chitosan, chitosan-poly (D-glucosamine) prepared from SIGMAALDRICH, and the Khazra nano fertilizer $\left(5 \%\right.$ of $\mathrm{Mg}$ ) were used at $2 \mathrm{~g} \mathrm{~L}^{-1}$ concentration for nano-Mg.

\section{Free proline content}

Leaf free proline content was determined by using Bates et al. (1973) method, $0.5 \mathrm{~g}$ of the fresh leaf was ground with quarts in porcelain pestle and mortar and treated with $10 \mathrm{~mL}$ sulfosalicylic acid, and the homogenate was centrifuged at $13000 \mathrm{~g}$ for $10 \mathrm{~min}$. Two $\mathrm{mL}$ of the filtrated extracts was transferred to tubes with cover, treated with $2 \mathrm{~mL}$ of ninhydrin indicator, and $2 \mathrm{~mL}$ of glacial acetic acid. The tubes were placed in boiling water at $100^{\circ} \mathrm{C}$ for $1 \mathrm{~h}$. The tubes were cool down and treated with $4 \mathrm{~mL}$ of toluene and shaken with a vortex for 15 to $20 \mathrm{~S}$. The red surface layer and standard samples were simultaneously placed in a spectrophotometer and the absorption of the samples was determined at the wavelength of 520 nanometer. The amount of proline content $\left(\mu \mathrm{mol} \mathrm{g}{ }^{-1} \mathrm{FW}\right)$ was calculated by using regression equations and the standard curves.

\section{Total carbohydrate content}

In order to estimate the total carbohydrate, $0.1 \mathrm{~g}$ sample was placed in a water bath with a Methanol $(80 \%)$ for $15 \mathrm{~min}$, and centrifuged at $10,000 \mathrm{~g}$ for $15 \mathrm{~min}$. The supernatant was used for the quantitative estimation of sugars by the method described by Morris (1948).

\section{Catalase activity (EC 1.11.1.6)}

The CAT activity assay was performed using Chance and Maehly (1955) method. Three mL reaction mixtures containing $2.5 \mathrm{~mL} 0.05 \mathrm{mM}$ sodium phosphate buffer $(\mathrm{pH}=7)$, and $30 \mu \mathrm{g}$ protein solution were added to quettes and $30 \mu \mathrm{L} \mathrm{H}_{2} \mathrm{O}_{2}(30 \%)$ was added to reaction mixture at the time of measurement, and the absorbance was recorded at 240 nanometers, $60 \mathrm{~s}$, and $25^{\circ} \mathrm{C}$.

\section{Peroxidase activity (EC 1.11.1)}

The activity of peroxidase enzyme was measured based on Wendel's (1981) method, in which $0.5 \mathrm{~g}$ of the plant tissue was homogenized with buffered potassium phosphate $(0.2 \mathrm{M}$ at $\mathrm{pH}=6.8)$ by using a cold porcelain pestle, centrifuged at $12000 \mathrm{~g}$ for $15 \mathrm{~min}$, and the the solution was used for measuring peroxidase activity. The reaction solution was incubated with $0.25 \mathrm{~mL}$ of the raw enzyme, $0.25 \mathrm{~mL}$ of guaiacol $\left(20 \mathrm{~g} \mathrm{~L}^{-1}\right)$ and $5.2 \mathrm{~mL}$ of buffer phosphate $(100 \mathrm{M}$ at $\mathrm{pH}=6.8)$ at $30{ }^{\circ} \mathrm{C}$ for $10 \mathrm{~min}$. The increased absorption was measured 3 min after adding $0.25 \mathrm{~mL}$ of $\mathrm{H}_{2} \mathrm{O}_{2}$ with the final concentration of $5 \mathrm{mM}$ using a spectrophotometer at the wavelength of $470 \mathrm{~nm}$. The standard solution $(100 \mathrm{~mL}$ at $\mathrm{pH}=6.8)$ containing $0.25 \mathrm{~mL}$ guayacol $0.5 \%$, $25 \mathrm{~mL} \mathrm{H}_{2} \mathrm{O}_{2}, 25 \mathrm{~mL}$ distilled water, and $2.25 \mathrm{~mL}$ buffered phosphate was used.

\section{Ascorbate peroxidase (EC 1.11.1.11)}

The activity of APX was determined according to the following details. $0.2 \mathrm{~g}$ fresh plant tissue was homogenized with $5 \mathrm{~mL}$ of a buffer solution with 1 mmole ascorbate, 1 mmole EDTA, and 50 mmole potassium phosphate $(\mathrm{pH}=7.0)$ by using a cold porcelain pestle. The extract was then filtrated and centrifuged for $10 \mathrm{~min}$ at $10000 \mathrm{~g}$, and the supernatant was used to determine the enzymatic activities. The solution contained 50 mmole potassium phosphate $(\mathrm{pH}=0.7), 0.5$ mmole ascorbate, 1 mmole $\mathrm{H}_{2} \mathrm{O}_{2}$, and $1 \mathrm{mmole}$ EDTA, and the total volume of the extracted enzyme was equal to $1 \mathrm{~mL}$. The reaction initiated with $\mathrm{H}_{2} \mathrm{O}_{2}$ and the rate of absorption was measured for 10-30 $s$ at the wavelength of 290 nanometer. The activity of enzyme was determined based on $\mu$ mole oxidized ascorbate per minute per mg protein (Asda, 1992). 


\section{Photosynthetic pigments}

In order to measure the content of photosynthetic pigments, the samples were immediately frozen in liquid nitrogen and kept in a freezer at $-80{ }^{\circ} \mathrm{C}$ before conducting the biochemical analyses. Then, the photosynthetic pigments were measured by using Lichtenthaler (1987) method. Based on this method, $0.25 \mathrm{~g}$ of fresh tissue was extracted by using $5 \mathrm{~mL} 80 \%$ acetone. Then, the extract was centrifuged at $11000 \mathrm{rpm}$ for $10 \mathrm{~min}$. In addition, the optical density (O.D.) of the extract was measured at the wavelengths of 646.8 and 663.2 nanometer to estimate chlorophyll a $(\mathrm{Chl}$ a) and b ( Chl b), respectively, by using a Spectrophotometer. The amount of pigment present in each sample was calculated according to the following equations:

$$
\begin{aligned}
& \text { Chl a }\left(\mathrm{mg} \mathrm{gr}^{-1} \mathrm{FW}\right)=12.7\left(\text { O. D of 663) }-2.69\left(\text { O. D of 645) } \times \frac{v}{w \times 1000}\right.\right. \\
& \text { Chl b }\left(\mathrm{mg} \mathrm{gr}^{-1} \mathrm{FW}\right)=22.9\left(\text { O. D of 645) }-4.68\left(\text { O. D of 663) } \times \frac{v}{w \times 1000}\right.\right. \\
& \text { Total Chl }\left(\mathrm{mg} \mathrm{gr}^{-1} \mathrm{FW}\right)=20.2\left(\text { O. D of 645) }+8.02\left(\text { O. D of 663) } \times \frac{v}{w \times 1000}\right.\right.
\end{aligned}
$$

Where $\mathrm{W}$ represents the fresh weight by grams for extracted tissue, $\mathrm{V}$ indicates the final size of the extract in $80 \%$ acetone, and O.D shows the optical density at a specific wavelength.

\section{Seed yield and oil content}

Seed yield was determined by collecting plants in a 5-m area at physiological maturity. Further, the amount of seed oil was determined by using the Soxhlet method according to the following details. The seeds were first dried using autoclave and then powdered. Using a cellulose cartridge, the samples were placed in the upper part of the Soxhlet apparatus. The volatilization of the solvent diethyl ether in the bottom of the apparatus resulted in solubilizing the oil, which was isolated, collected and weighed following the evaporation of the solvent. Then, oil percentage was multiplied in the seed yield in order to calculate the oil yield.

\section{Statistical analyses}

After checking the normality data distribution of data (Kolmogorov-Smirnov and Shapiro-Wilk test) assumption, the studied traits were statistically analysed by the Statistical Analysis System software (SAS Institute, Cary, NC, USA, Version 9.2). The differences among means were measured by using least significant difference test (LSD) at 0.05 statistical probability level and the graphs were drawn by MS-Excel.

\section{Results}

\section{Free proline content}

The effect of irrigation (I), $\mathrm{Mg}$ nano-chelate $(\mathrm{Mg})$, chitosan $(\mathrm{CH})$, and cultivar $(\mathrm{C})$ were significant on free proline content in both years of the experiment (Table 2). Based on the results, as shown in Table 2, irrigation up to flowering (severe stress $=\mathrm{I}_{3}$ ) caused an increase in free proline content during two years, compared to normal irrigation $\left(\mathrm{I}_{1}\right)$ (13.04 and 62.9\%). In addition, the application of $\mathrm{Mg}$ nano-chelate and chitosan resulted in increasing the content of free proline significantly during both years (Table 2 ). Further, 'Dashtestan' cultivar had the highest value of trait in both years. Regarding the interaction $\mathrm{Mg} \times \mathrm{C}$, the highest free proline content was related to the application of $\mathrm{Mg}$ in both cultivars in the first year and the use of $\mathrm{Mg}$ in 'Oltan' in the second year (Figure 3). 
Table 2. Effect of nano-Mg and chitosan on proline content, total sugars, activity of CAT, POD, and APX enzymes of sesame cultivars under water-limited stress

\begin{tabular}{|c|c|c|c|c|c|c|c|c|c|c|}
\hline \multirow[t]{2}{*}{ Treatment } & \multicolumn{2}{|c|}{$\begin{array}{c}\text { Proline } \\
\text { content } \\
\left(\mu \mathrm{mol} \mathrm{g}^{-1} \mathrm{FW}\right)\end{array}$} & \multicolumn{2}{|c|}{$\begin{array}{l}\text { Total sugars } \\
\left(\mathrm{mg} \mathrm{g}^{-1} \mathrm{FW}\right)\end{array}$} & \multicolumn{2}{|c|}{$\begin{array}{c}\text { CAT } \\
(\mathrm{U} \text { min.mg } \\
\left.\text { protein }^{-1}\right) \\
\end{array}$} & \multicolumn{2}{|c|}{$\begin{array}{c}\text { POD } \\
(\mathrm{U} \text { min.mg } \\
\left.\text { protein }^{-1}\right) \\
\end{array}$} & \multicolumn{2}{|c|}{$\begin{array}{c}\text { APX } \\
(\mathrm{U} \text { min.mg } \\
\left.\text { protein }^{-1}\right) \\
\end{array}$} \\
\hline & 2015 & 2016 & 2015 & 2016 & 2015 & 2016 & 2015 & 2016 & 2015 & 2016 \\
\hline \multicolumn{11}{|l|}{ Irrigation (I) } \\
\hline $\mathrm{I}_{1}$ & 0.80 & 0.97 & 10.47 & 9.78 & 2.87 & 1.71 & 1.81 & 1.40 & 8.31 & 4.16 \\
\hline $\mathrm{I}_{2}$ & 0.86 & 1.42 & 10.62 & 10.39 & 4.26 & 3.53 & 2.47 & 2.23 & 10.74 & 5.33 \\
\hline $\mathrm{I}_{3}$ & 0.92 & 1.54 & 10.97 & 11.20 & 4.95 & 3.91 & 5.46 & 4.09 & 18.05 & 9.81 \\
\hline St D $( \pm)$ & 0.11 & 0.17 & 0.53 & 0.53 & 1.49 & 1.23 & 0.79 & 0.75 & 4.43 & 3.91 \\
\hline $\operatorname{LSD}(P=0.05)$ & 0.86 & 0.07 & 0.34 & 0.28 & 0.58 & 0.29 & 0.43 & 0.33 & 4.05 & 0.95 \\
\hline \multicolumn{11}{|l|}{ Nano-Mg } \\
\hline Control & 0.84 & 1.27 & 10.62 & 10.39 & 4.18 & 3.20 & 3.34 & 2.65 & 12.61 & 6.49 \\
\hline Application & 0.87 & 1.34 & 10.75 & 10.52 & 3.87 & 2.90 & 3.15 & 2.50 & 12.12 & 6.38 \\
\hline St D $( \pm)$ & 0.12 & 028 & 0.59 & 0.80 & 1.72 & 1.56 & 1.81 & 1.38 & 6.22 & 4.82 \\
\hline $\operatorname{LSD}(P=0.05)$ & NS & 0.04 & NS & NS & 0.23 & 0.15 & NS & NS & NS & NS \\
\hline \multicolumn{11}{|l|}{ Chitosan $(\mathrm{CH})$} \\
\hline $\mathrm{CH} 1$ & 0.82 & 1.27 & 10.39 & 10.17 & 4.03 & 2.98 & 3.17 & 2.57 & 15.13 & 9.81 \\
\hline $\mathrm{CH} 2$ & 0.91 & 1.36 & 10.67 & 10.44 & 3.84 & 2.94 & 2.58 & 1.94 & 8.89 & 3.86 \\
\hline $\mathrm{CH} 3$ & 0.84 & 1.29 & 10.99 & 10.76 & 4.21 & 3.24 & 3.99 & 3.21 & 13.09 & 5.63 \\
\hline St D $( \pm)$ & 0.12 & 0.29 & 0.51 & 0.74 & 1.69 & 1.54 & 1.71 & 1.29 & 5.55 & 3.95 \\
\hline $\operatorname{LSD}(P=0.05)$ & 0.05 & 0.05 & 0.23 & 0.23 & 0.28 & 0.19 & 0.29 & 0.23 & 1.67 & 1.40 \\
\hline \multicolumn{11}{|l|}{ Cultivar (C) } \\
\hline 'Oltan' (C1) & 0.82 & 1.23 & 10.66 & 10.53 & 5.05 & 3.94 & 3.38 & 2.71 & 12.67 & 6.77 \\
\hline $\begin{array}{c}\text { 'Dashtestan-2' } \\
\text { (C2) }\end{array}$ & 0.89 & 1.39 & 10.71 & 10.38 & 3.00 & 2.16 & 3.11 & 2.44 & 12.07 & 6.09 \\
\hline St D $( \pm)$ & 0.12 & 0.28 & 0.61 & 0.82 & 1.39 & 1.29 & 1.80 & 1.39 & 6.23 & 4.89 \\
\hline $\operatorname{LSD}(P=0.05)$ & 0.04 & 0.04 & NS & NS & 0.23 & 0.15 & 0.24 & 0.19 & NS & NS \\
\hline \multicolumn{11}{|l|}{$\begin{array}{c}\text { Interaction } \\
\text { effect }\end{array}$} \\
\hline $\mathrm{I} \times \mathrm{Mg}$ & NS & ** & $*$ & * & $* *$ & $*$ & ** & ** & NS & NS \\
\hline $\mathrm{I} \times \mathrm{CH}$ & NS & NS & ** & ** & $* *$ & $* *$ & * & ** & $* *$ & ** \\
\hline $\mathrm{I} \times \mathrm{C}$ & NS & ** & NS & NS & * & ** & NS & * & NS & NS \\
\hline $\mathrm{Mg} \times \mathrm{CH}$ & NS & NS & NS & NS & * & * & NS & NS & NS & * \\
\hline $\mathrm{Mg} \times \mathrm{C}$ & $*$ & $*$ & NS & NS & ** & ** & NS & $*$ & NS & NS \\
\hline $\mathrm{CH} \times \mathrm{C}$ & NS & NS & NS & NS & ** & $* *$ & NS & NS & NS & NS \\
\hline $\mathrm{I} \times \mathrm{Mg} \times \mathrm{CH}$ & NS & NS & NS & NS & NS & NS & NS & NS & NS & * \\
\hline $\mathrm{I} \times \mathrm{Mg} \times \mathrm{C}$ & NS & NS & * & NS & * & ** & NS & * & NS & NS \\
\hline $\mathrm{I} \times \mathrm{CH} \times \mathrm{C}$ & NS & NS & NS & NS & ** & $* *$ & NS & NS & NS & NS \\
\hline $\mathrm{Mg} \times \mathrm{CH} \times \mathrm{C}$ & NS & NS & NS & NS & * & $* *$ & NS & NS & NS & NS \\
\hline $\begin{array}{c}\mathrm{I} \times \mathrm{Mg} \times \mathrm{CH} \times \\
\mathrm{C}\end{array}$ & NS & NS & NS & NS & NS & $*$ & NS & $*$ & NS & NS \\
\hline
\end{tabular}

LSD: least significant difference; NS: non-significant, ${ }^{*}$ and ${ }^{* *}$ significant 5 and $1 \%$ probably levels.

I1: normal irrigation; I2: irrigation cut-off in seed ripening ( $75 \mathrm{BBCH}$ stage); I3: irrigation cut-off in flowering (65 $\mathrm{BBCH}$ stage); $\mathrm{CH} 1$ : non-application of chitosan; $\mathrm{CH} 2: 4.6 \mathrm{~g} \mathrm{~L}^{-1}$; $\mathrm{CH} 3: 6.4 \mathrm{~g} \mathrm{~L}^{-1}$; 


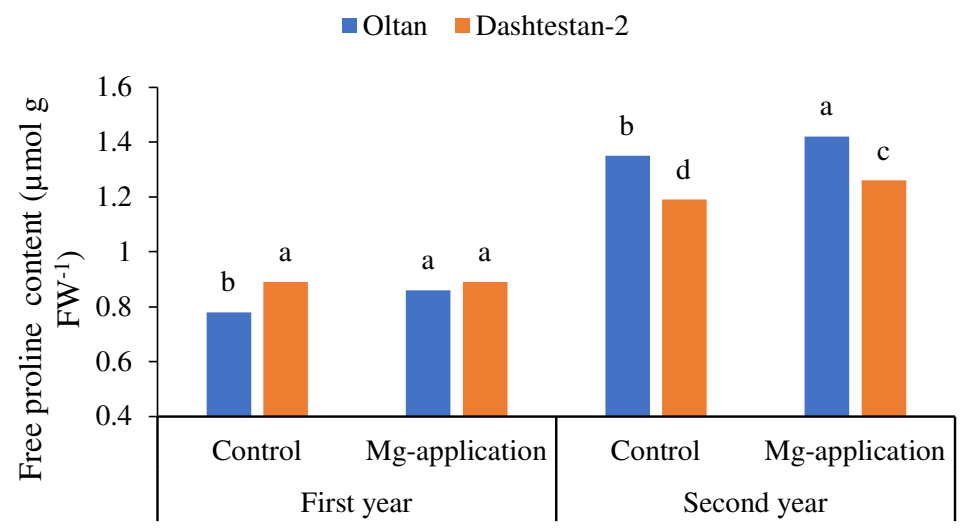

Figure 3. Free proline content affected by different sesame cultivars and nano-Mg chelate treatments, columns (for each year) with different letters are significantly different at $P=0.05$, using LSD test

\section{Total sugars}

As indicated in Table 2, the effect of $\mathrm{I}, \mathrm{CH}, \mathrm{I} \times \mathrm{Mg}$, and $\mathrm{I} \times \mathrm{CH}$ was significant on the total sugars in both years. The results indicated that the severe stress $\left(\mathrm{I}_{3}\right)$ and the application of $6.4 \mathrm{~g} \mathrm{~L}^{-1}$ chitosan led to an increase in the total sugars in both years (Table 2). In the interaction $\mathrm{I} \times \mathrm{Mg}$, the maximum rate of total sugars was related to non-application of $\mathrm{Mg}$ under $\mathrm{I}_{3}$ by 11.0 and $11.2 \mathrm{mg} \mathrm{g}^{-1} \mathrm{FW}$ in the first and second years, respectively, while the lowest was related to non-application of $\mathrm{Mg}$ under $\mathrm{I}_{1}$ (normal irrigation) by 10.2 and 9.5 $\mathrm{mg} \mathrm{g}^{-1} \mathrm{FW}$ in the first and second years, respectively (Table 3 ). Regarding the interaction $\mathrm{I} \times \mathrm{CH}$, the maximum rate of sugars was created by $\mathrm{CH}_{3}\left(6.4 \mathrm{~g} \mathrm{~L}^{-1}\right.$ chitosan $)$ and $\mathrm{I}_{3}$ by 11.7 and $11.9 \mathrm{mg} \mathrm{g}^{-1} \mathrm{FW}$ in the first and second years, respectively, and the minimum was related to $\mathrm{I}_{1}$ and $\mathrm{CH}_{1}$ (non-application of chitosan) by 10.3 and 9.6 $\mathrm{mg} \mathrm{g}^{-1} \mathrm{FW}$ in the first and second years, respectively (Table 3 ).

\section{Antioxidant enzyme activities}

As shown in Table 2, the effect of $\mathrm{I}, \mathrm{CH}$, and $\mathrm{I} \times \mathrm{CH}$ was significant on CAT, POD, and APX activities. Based on the results, the limited irrigation $\left(\mathrm{I}_{3}\right)$ results in increasing CAT, POD, and APX activities and the lowest activity is related to $\mathrm{I}_{1}$ treatment (Table 2). Regarding the interaction $\mathrm{I} \times \mathrm{Mg}$, the highest CAT and POD activities were related to CAT: 5.1 and 4.1, and POD: 5.5 and $4.4 \mathrm{U}$ min.mg protein ${ }^{-1}$ for the first and second years, respectively. As shown in Table 3, the lowest activities were observed in I1 in both levels of $\mathrm{Mg}$ treatment. However, CAT activity was in the range of 5.5 and 4.2 in first and second years for $\mathrm{I}_{3} \times \mathrm{CH}_{2}$ and 2.6 and $1.5 \mathrm{U}$ min.mg protein ${ }^{-1}$ in the first and second years for $\mathrm{I}_{1} \times \mathrm{CH}_{2}$ (Table 3). A similar result was observed for POD activity, which was in the range of 6.5 and 4.9 in the first and second years for $\mathrm{I}_{3} \times \mathrm{CH}_{3}$ and 1.4 and $1.1 \mathrm{U}$ min.mg protein ${ }^{-1}$ in the first and second years for $\mathrm{I}_{1} \times \mathrm{CH}_{2}$ (Table 3). In addition, the highest APX activity (22.79 and $16.5 \mathrm{U}$ min.mg protein ${ }^{-1}$ in the first and second years, respectively) was achieved in the non-application of chitosan under $\mathrm{I}_{3}$. As illustrated in Figure 4, the lowest trait was related to the application of 6.4 and $4.8 \mathrm{~g} \mathrm{~L}^{-1}$ chitosan under $\mathrm{I}_{1}$ and $\mathrm{I}_{2}$, respectively. 
Table 3. Total sugars, CAT and POD activities, seed yield, oil percentage and yield affected by irrigation

$(\mathrm{I}) \times$ nano- $\mathrm{Mg}(\mathrm{Mg})$ and irrigation $\times$ chitosan $(\mathrm{CH})$ treatments during two years

\begin{tabular}{|c|c|c|c|c|c|c|c|c|c|c|c|c|c|}
\hline \multirow{2}{*}{\multicolumn{2}{|c|}{$\mathrm{I} \times \mathrm{Mg}$}} & \multicolumn{2}{|c|}{$\begin{array}{l}\text { Total sugars } \\
\left(\mathrm{mgg}^{-1} \mathrm{FW}\right)\end{array}$} & \multicolumn{2}{|c|}{$\begin{array}{c}\text { CAT } \\
\left(\mathrm{U} \text { min.mg protein }{ }^{-1}\right)\end{array}$} & \multicolumn{2}{|c|}{$\begin{array}{c}\text { POD } \\
(\mathrm{U} \text { min.mg } \\
\left.\text { protein }^{-1}\right)\end{array}$} & \multicolumn{2}{|c|}{$\begin{array}{l}\text { Seed yield } \\
\left(\mathrm{kg} \mathrm{ha}^{-1}\right)\end{array}$} & \multicolumn{2}{|c|}{$\begin{array}{l}\text { Oil percentage } \\
(\%)\end{array}$} & \multicolumn{2}{|c|}{$\begin{array}{l}\text { Oil yield } \\
\left(\mathrm{kg} \mathrm{ha}^{-1}\right)\end{array}$} \\
\hline & & 2015 & 2016 & 2015 & 2016 & 2015 & 2016 & 2015 & 2016 & 2015 & 2016 & 2015 & 2016 \\
\hline \multirow[b]{2}{*}{ Il } & Control & $10.2 \mathrm{c}$ & $9.5 \mathrm{~d}$ & $2.9 \mathrm{~d}$ & $1.7 \mathrm{~d}$ & $1.9 \mathrm{c}$ & $1.5 \mathrm{~d}$ & $948.7 \mathrm{~b}$ & $978.8 \mathrm{~b}$ & $48.2 \mathrm{a}$ & $47.7 \mathrm{~b}$ & $462.8 \mathrm{~b}$ & $469.5 \mathrm{~b}$ \\
\hline & Application & $10.7 \mathrm{ab}$ & $10.0 \mathrm{c}$ & $2.7 \mathrm{~d}$ & $1.6 \mathrm{~d}$ & $1.7 \mathrm{c}$ & $1.2 \mathrm{~d}$ & $\begin{array}{c}1112.0 \\
\mathrm{a}\end{array}$ & $\begin{array}{c}1293.9 \\
\mathrm{a}\end{array}$ & $48.4 \mathrm{a}$ & $52.8 \mathrm{a}$ & $545.7 \mathrm{a}$ & $687.4 \mathrm{a}$ \\
\hline \multirow{2}{*}{ I2 } & Control & $10.5 \mathrm{~b}$ & $10.3 \mathrm{bc}$ & $4.4 \mathrm{~b}$ & $3.6 \mathrm{~b}$ & $2.5 \mathrm{~b}$ & $1.2 \mathrm{~d}$ & $537.9 \mathrm{~d}$ & $652.2 \mathrm{~d}$ & $41.3 \mathrm{c}$ & $41.8 \mathrm{~d}$ & $225.3 \mathrm{~d}$ & $274.5 \mathrm{~d}$ \\
\hline & Application & $10.6 \mathrm{~b}$ & $10.4 \mathrm{~b}$ & $4.0 \mathrm{c}$ & $3.3 \mathrm{c}$ & $2.3 \mathrm{~b}$ & $2.1 \mathrm{c}$ & $727.4 \mathrm{c}$ & $816.2 \mathrm{c}$ & $44.4 \mathrm{~b}$ & $43.7 \mathrm{c}$ & $326.2 \mathrm{c}$ & $358.4 \mathrm{c}$ \\
\hline \multirow{2}{*}{ I3 } & Control & $11.0 \mathrm{a}$ & $11.2 \mathrm{a}$ & $5.1 \mathrm{a}$ & $4.1 \mathrm{a}$ & $5.5 \mathrm{a}$ & $4.4 \mathrm{a}$ & $459.5 \mathrm{e}$ & $467.9 \mathrm{f}$ & $37.4 \mathrm{~d}$ & $38.8 \mathrm{e}$ & $173.6 \mathrm{e}$ & $182.9 \mathrm{f}$ \\
\hline & Application & $10.8 \mathrm{ab}$ & $11.1 \mathrm{a}$ & $4.7 \mathrm{ab}$ & $3.6 \mathrm{~b}$ & $5.4 \mathrm{a}$ & $3.7 \mathrm{~b}$ & $507.9 \mathrm{~d}$ & $519.5 \mathrm{e}$ & $36.9 \mathrm{~d}$ & $41.2 \mathrm{~d}$ & $189.7 \mathrm{e}$ & $215.0 \mathrm{e}$ \\
\hline \multicolumn{14}{|c|}{$\mathrm{I} \times \mathrm{CH}$} \\
\hline \multirow{3}{*}{ Il } & $\mathrm{CH} 1$ & $10.3 \mathrm{c}$ & $9.6 \mathrm{f}$ & $3.0 \mathrm{~d}$ & $1.6 \mathrm{f}$ & $1.7 \mathrm{~g}$ & $1.1 \mathrm{f}$ & $836.9 \mathrm{c}$ & $973.9 \mathrm{c}$ & $44.0 \mathrm{~cd}$ & $47.9 \mathrm{c}$ & $371.2 \mathrm{c}$ & $472.0 \mathrm{c}$ \\
\hline & $\mathrm{CH} 2$ & $10.5 \mathrm{bc}$ & $9.8 \mathrm{ef}$ & $2.6 \mathrm{~d}$ & $1.5 \mathrm{f}$ & $1.4 \mathrm{~g}$ & $1.1 \mathrm{f}$ & $\begin{array}{c}1019.2 \\
\mathrm{~b}\end{array}$ & $\begin{array}{c}1139.7 \\
\mathrm{~b}\end{array}$ & $49.2 \mathrm{~b}$ & $50.3 \mathrm{~b}$ & $501.2 \mathrm{~b}$ & $578.4 \mathrm{~b}$ \\
\hline & $\mathrm{CH} 3$ & $10.5 \mathrm{bc}$ & $9.8 \mathrm{ef}$ & $2.9 \mathrm{~d}$ & $1.8 \mathrm{f}$ & $2.2 \mathrm{ef}$ & $1.9 \mathrm{de}$ & $\begin{array}{c}1235.1 \\
\mathrm{a} \\
\end{array}$ & $\begin{array}{c}1295.5 \\
\mathrm{a} \\
\end{array}$ & $51.7 \mathrm{a}$ & $52.4 \mathrm{a}$ & $640.3 \mathrm{a}$ & $685.0 \mathrm{a}$ \\
\hline \multirow{3}{*}{ I2 } & $\mathrm{CH1}$ & $10.3 \mathrm{bc}$ & $10.1 \mathrm{de}$ & $4.4 \mathrm{~b}$ & $3.6 \mathrm{~cd}$ & $2.4 \mathrm{e}$ & $2.3 \mathrm{~d}$ & $504.6 \mathrm{f}$ & $614.5 \mathrm{f}$ & $40.5 \mathrm{e}$ & $41.1 \mathrm{fg}$ & $206.1 \mathrm{f}$ & $253.9 \mathrm{f}$ \\
\hline & $\mathrm{CH} 2$ & $10.7 \mathrm{~b}$ & $10.5 \mathrm{bcd}$ & $3.9 \mathrm{c}$ & $3.1 \mathrm{e}$ & $1.7 \mathrm{fg}$ & $1.6 \mathrm{e}$ & $626.1 \mathrm{e}$ & $742.4 \mathrm{e}$ & $43.1 \mathrm{~d}$ & $42.9 \mathrm{de}$ & $272.0 \mathrm{~d}$ & $320.2 \mathrm{e}$ \\
\hline & $\mathrm{CH} 3$ & $10.7 \mathrm{bc}$ & $10.4 \mathrm{~cd}$ & $4.4 \mathrm{bc}$ & $3.8 \mathrm{bc}$ & $3.1 \mathrm{~d}$ & $2.7 \mathrm{c}$ & $767.2 \mathrm{~d}$ & $845.7 \mathrm{~d}$ & $45.1 \mathrm{c}$ & $44.2 \mathrm{~d}$ & $349.1 \mathrm{c}$ & $375.3 \mathrm{~d}$ \\
\hline \multirow{3}{*}{ I3 } & $\mathrm{CH} 1$ & $10.4 b c$ & $10.7 \mathrm{bc}$ & $4.0 \mathrm{bc}$ & $3.4 \mathrm{~d}$ & $5.3 \mathrm{~b}$ & $4.2 \mathrm{~b}$ & $373.0 \mathrm{~g}$ & $415.7 \mathrm{i}$ & $34.6 \mathrm{~g}$ & $37.9 \mathrm{~h}$ & $128.9 \mathrm{~g}$ & $158.1 \mathrm{~h}$ \\
\hline & $\mathrm{CH} 2$ & $10.6 \mathrm{bc}$ & $10.9 \mathrm{~b}$ & $5.5 \mathrm{a}$ & $4.2 \mathrm{a}$ & $4.5 \mathrm{c}$ & $3.0 \mathrm{c}$ & $485.1 \mathrm{f}$ & $492.2 \mathrm{~h}$ & $36.9 \mathrm{f}$ & $40.0 \mathrm{~g}$ & $179.2 \mathrm{f}$ & $197.5 \mathrm{~g}$ \\
\hline & $\mathrm{CH} 3$ & $11.7 \mathrm{a}$ & $11.9 \mathrm{a}$ & $4.2 \mathrm{a}$ & $4.0 \mathrm{ab}$ & $6.5 \mathrm{a}$ & $4.9 \mathrm{a}$ & $592.9 \mathrm{e}$ & $573.2 \mathrm{~g}$ & $39.9 \mathrm{e}$ & $42.1 \mathrm{ef}$ & $236.7 \mathrm{e}$ & $241.3 \mathrm{f}$ \\
\hline
\end{tabular}

Columns (for each year) with different letters are significantly different at $P=0.05$, using LSD test.

I1: normal irrigation; I2: irrigation cut-off in seed ripening ( $75 \mathrm{BBCH}$ stage); I3: irrigation cut-off in flowering (65

$\mathrm{BBCH}$ stage); $\mathrm{CH} 1$ : non-application of chitosan; $\mathrm{CH} 2: 4.6 \mathrm{~g} \mathrm{~L}^{-1}$; $\mathrm{CH} 3: 6.4 \mathrm{~g} \mathrm{~L}^{-1}$;

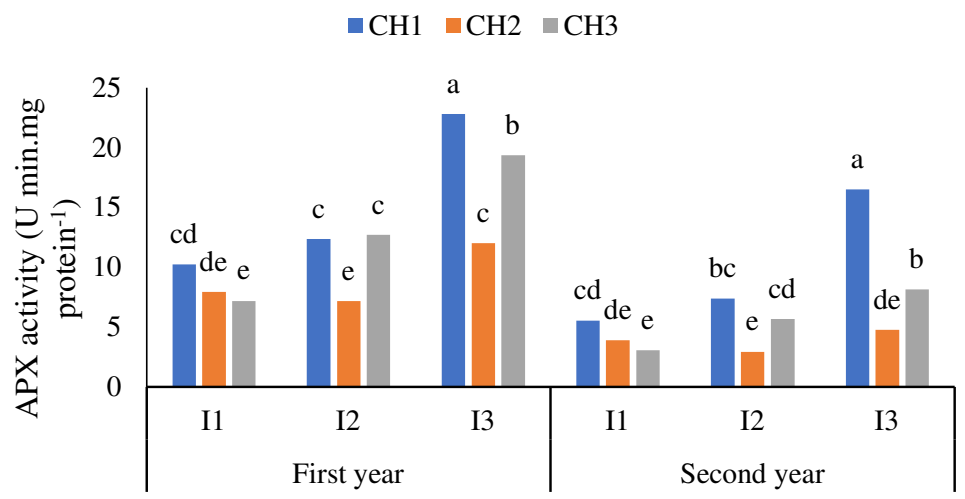

Figure 4. APX activity affected by water-limited and chitosan treatments, columns (for each year) with different letters are significantly different at $P=0.05$, using LSD test

\section{Photosynthetic pigments}

Based on the results, I, CH, and $\mathrm{Mg} \times$ cultivars $(\mathrm{C})$ affected chlorophyll a, b, and the total contents significantly (Table 4). In addition, as shown in Table 4, the irrigation up to flowering (severe stress) caused a significant decrease in chlorophyll a and the total, while irrigation up to seed ripening (mild stress) could increase chlorophyll $b$, compared to the control treatment $\left(\mathrm{I}_{1}\right)$. Further, the application of chitosan resulted in increasing chlorophyll a and the total contents. 'Dashtestan-2' cultivar had higher chlorophyll a and the total, compared to the amount in 'Oltan'. However, 'Oltan' had the highest chlorophyll b content (Table 4). As illustrated in Fig. 5, the highest chlorophyll a content in interaction $\mathrm{Mg} \times \mathrm{C}$ was related to the application of $\mathrm{Mg}$ in both cultivars and non-application of Mg in 'Dashtestan-2' and the lowest was related to the nonapplication of $\mathrm{Mg}$ in 'Oltan' cultivar during the two years of the experiment. Further, the non-application of $\mathrm{Mg}$ in 'Dashtestan-2' had the highest content of chlorophyll b 7.76 and $8.36 \mu \mathrm{g} \mathrm{g}^{-1} \mathrm{FW}$ in the first and second years, respectively). However, as shown in Fig. 6, the lowest was related to the application of Mg in 'Dashtestan$2^{\prime}$ (6.53 and $7.01 \mu \mathrm{g} \mathrm{g}^{-1} \mathrm{FW}$ in the first and second years, respectively). In the first and second years, the total 
chlorophyll content was in the range of 22.22 and 26.15 for the application of Mg in 'Oltan' to 20.1 and 23.82 $\mu \mathrm{g} \mathrm{g}^{-1} \mathrm{FW}$ for the non-application of Mg in 'Oltan', respectively (Figure 5).

Table 4. Effect of nano-Mg and chitosan on chlorophyll a, b, and total of sesame cultivars under waterlimited stress

\begin{tabular}{|c|c|c|c|c|c|c|}
\hline \multirow[t]{2}{*}{ Treatment } & \multicolumn{2}{|c|}{$\begin{array}{l}\text { Chlorophyll a } \\
\left(\mathrm{mg} \mathrm{g}^{-1} \mathrm{FW}\right)\end{array}$} & \multicolumn{2}{|c|}{$\begin{array}{l}\text { Chlorophyll b } \\
\left(\mathrm{mg} \mathrm{g}^{-1} \mathrm{FW}\right)\end{array}$} & \multicolumn{2}{|c|}{$\begin{array}{l}\text { Total chlorophyll } \\
\left(\mathrm{mg} \mathrm{g}^{-1} \mathrm{FW}\right)\end{array}$} \\
\hline & 2015 & 2016 & 2015 & 2016 & 2015 & 2016 \\
\hline \multicolumn{7}{|l|}{ Irrigation (I) } \\
\hline $\mathrm{I}_{1}$ & 15.31 & 18.98 & 8.21 & 8.48 & 23.52 & 27.46 \\
\hline $\mathrm{I}_{2}$ & 15.08 & 18.27 & 8.33 & 8.96 & 23.42 & 27.23 \\
\hline $\mathrm{I}_{3}$ & 12.11 & 15.09 & 5.22 & 5.96 & 17.33 & 21.05 \\
\hline St D $( \pm)$ & 1.87 & 2.11 & 2.28 & 2.55 & 2.60 & 2.72 \\
\hline $\operatorname{LSD}(P=0.05)$ & 1.31 & 1.36 & 1.07 & 0.88 & 0.95 & 1.80 \\
\hline \multicolumn{7}{|l|}{ Nano-Mg } \\
\hline Control & 13.63 & 16.75 & 7.44 & 8.04 & 21.08 & 24.79 \\
\hline Application & 14.70 & 18.15 & 7.07 & 7.55 & 21.77 & 25.71 \\
\hline St D $( \pm)$ & 2.31 & 2.60 & 2.68 & 2.86 & 3.89 & 4.03 \\
\hline $\operatorname{LSD}(P=0.05)$ & 0.63 & 0.62 & NS & NS & NS & NS \\
\hline \multicolumn{7}{|l|}{ Chitosan $(\mathrm{CH})$} \\
\hline $\mathrm{CH} 1$ & 13.63 & 16.69 & 7.94 & 8.03 & 21.58 & 27.72 \\
\hline $\mathrm{CH} 2$ & 14.45 & 17.21 & 7.15 & 9.13 & 21.60 & 26.34 \\
\hline $\mathrm{CH} 3$ & 14.41 & 18.44 & 6.67 & 6.23 & 21.09 & 24.68 \\
\hline St D $( \pm)$ & 2.34 & 2.60 & 2.66 & 2.62 & 3.92 & 3.99 \\
\hline $\operatorname{LSD}(P=0.05)$ & 0.78 & 0.76 & 1.02 & 1.07 & NS & 1.14 \\
\hline \multicolumn{7}{|l|}{ Cultivar (C) } \\
\hline 'Oltan' (C1) & 13.79 & 17.08 & 7.36 & 7.90 & 21.16 & 24.99 \\
\hline 'Dashtestan-2' (C2) & 14.54 & 17.82 & 7.15 & 7.69 & 21.69 & 25.51 \\
\hline St D $( \pm)$ & 2.33 & 2.67 & 2.69 & 2.87 & 3.89 & 4.03 \\
\hline $\operatorname{LSD}(P=0.05)$ & 0.63 & 0.62 & 0.83 & NS & 0.88 & NS \\
\hline \multicolumn{7}{|l|}{ Interaction effect } \\
\hline $\mathrm{I} \times \mathrm{Mg}$ & * & $* *$ & NS & NS & NS & NS \\
\hline $\mathrm{I} \times \mathrm{CH}$ & ** & ** & NS & NS & NS & NS \\
\hline $\mathrm{I} \times \mathrm{C}$ & NS & NS & * & ${ }^{*}$ & * & * \\
\hline $\mathrm{Mg} \times \mathrm{CH}$ & NS & NS & NS & NS & * & * \\
\hline $\mathrm{Mg} \times \mathrm{C}$ & * & * & * & * & ** & ** \\
\hline $\mathrm{CH} \times \mathrm{C}$ & NS & NS & NS & NS & NS & NS \\
\hline $\mathrm{I} \times \mathrm{Mg} \times \mathrm{CH}$ & NS & NS & $*$ & ${ }^{*}$ & NS & NS \\
\hline $\mathrm{I} \times \mathrm{Mg} \times \mathrm{C}$ & NS & NS & NS & NS & NS & NS \\
\hline $\mathrm{I} \times \mathrm{CH} \times \mathrm{C}$ & NS & NS & NS & NS & NS & NS \\
\hline $\mathrm{Mg} \times \mathrm{CH} \times \mathrm{C}$ & NS & NS & NS & NS & NS & NS \\
\hline $\mathrm{I} \times \mathrm{Mg} \times \mathrm{CH} \times \mathrm{C}$ & NS & NS & NS & NS & NS & NS \\
\hline
\end{tabular}

LSD: least significant difference; NS: non-significant, ${ }^{*}$ and ${ }^{* *}$ significant 5 and $1 \%$ probably levels.

I1: normal irrigation; I2: irrigation cut-off in seed ripening ( $75 \mathrm{BBCH}$ stage); I3: irrigation cut-off in flowering (65 $\mathrm{BBCH}$ stage); $\mathrm{CH} 1$ : non-application of chitosan; $\mathrm{CH} 2: 4.6 \mathrm{~g} \mathrm{~L}^{-1}$; CH3: $6.4 \mathrm{~g} \mathrm{~L}^{-1}$; 


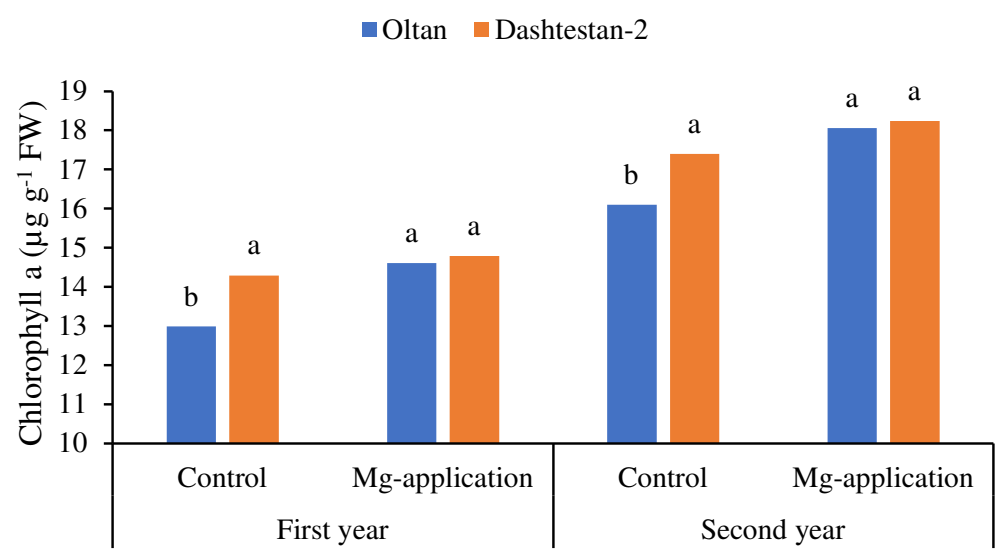

Figure 5. Chlorophyll a content affected by different sesame cultivars and nano-Mg chelate treatments, columns (for each year) with different letters are significantly different at $P=0.05$, using LSD test

\section{Seed yield}

As shown in Table 5, the effect of $\mathrm{I}, \mathrm{Mg}, \mathrm{CH}, \mathrm{C}, \mathrm{I} \times \mathrm{Mg}, \mathrm{I} \times \mathrm{CH}$ on seed yield was significant. Further, severe stress caused a decrease in 53.0 and $56.5 \%$ during the first and second years, respectively, compared to the amount in the normal irrigation. Regarding the comparison of mean effects, the application of $\mathrm{Mg}$ and chitosan enhanced seed yield significantly, compared to the amount in the control treatment (Table 5). Furthermore, 'Dashtestan-2' cultivar had the highest seed yield, compared to 'Oltan' cultivar. In addition, the highest seed yield in the interaction I × Mg was achieved by applying Mg in $\mathrm{I}_{1}$ treatment (1112 and $1293.9 \mathrm{~kg}$ $\mathrm{ha}^{-1}$ for the first and second years, respectively). As indicated in Table 3, the lowest trait was related to the nonapplication of $\mathrm{Mg}$ in $\mathrm{I}_{3}$ (459.5 and $467.9 \mathrm{~kg} \mathrm{ha}^{-1}$ for the first and second years, respectively). Regarding the interaction $\mathrm{I} \times \mathrm{CH}$, the seed yield ranged from 1235.1 and 1295.5 (I1 and $\mathrm{CH} 3$ for the first and second years) to 373.0 and $415.7 \mathrm{~kg} \mathrm{ha}^{-1}$ ( $\mathrm{I}_{3}$ and $\mathrm{CH} 1$ for the first and second years) (Table 3 ).

\section{Seed oil content}

The results indicated that the effect of $\mathrm{I}, \mathrm{Mg}, \mathrm{CH}, \mathrm{I} \times \mathrm{Mg}$, and $\mathrm{I} \times \mathrm{CH}$ on the oil percentage and yield was significant in both years (Table 5). In addition, an increase in the level of stress leads to a decrease in the oil percentage and yield under $\mathrm{I}_{3}$. Further, adding $\mathrm{Mg}$ increased the oil percentage from 42.35 to 43.29 during the first year and 42.82 to $45.92 \%$ during the second year). Furthermore, as shown in Table 5, oil yield increased from 287.2 to 353.8 in the first year, and 309.0 to $420.3 \mathrm{~kg} \mathrm{ha}^{-1}$ in the second year). Additionally, an increase occurred in seed oil percentage and yield under chitosan application, compared to the amount in the control treatment (Table 5). As indicated in Table 3, the highest oil percentage (48.4 and 52.8\%) and oil yield (545.7 and $687.4 \mathrm{~kg} \mathrm{ha}^{-1}$ ) were related to the application of $\mathrm{Mg}$ under $\mathrm{I}_{1}$. However, the lowest oil percentage ( 37.4 and $38.8 \%$ ) and oil yield (173.6 and $182.9 \mathrm{~kg} \mathrm{ha}^{-1}$ ) were observed in the non-application of $\mathrm{Mg}$ under $\mathrm{I}_{3}$ (Table 3). Regarding the interaction $\mathrm{I} \times \mathrm{CH}$, the oil percentage ranged 34.6 and 37.9 in the first and second year in $\mathrm{I}_{3}$ and $\mathrm{CH} 1$ to 51.7 and $52.4 \%$ in the first and second years in $\mathrm{I}_{1}$ and $\mathrm{CH}_{3}$. Finally, as shown in Table 3, the highest oil yield was related to $\mathrm{I}_{1}$ and $\mathrm{CH} 3\left(640.3\right.$ and $\left.685.0 \mathrm{~kg} \mathrm{ha}^{-1}\right)$ while the lowest belonged to $\mathrm{I}_{3}$ and $\mathrm{CH} 1$ (128.9 and $\left.158.1 \mathrm{~kg} \mathrm{ha}^{-1}\right)$. 
Table 5. Effect of nano-Mg and chitosan on seed yield, oil percentage and yield of sesame cultivars under water-limited stress

\begin{tabular}{|c|c|c|c|c|c|c|}
\hline \multirow[t]{2}{*}{ Treatment } & \multicolumn{2}{|c|}{$\begin{array}{c}\text { Seed yield } \\
\left(\mathrm{kg} \mathrm{ha}^{-1}\right)\end{array}$} & \multicolumn{2}{|c|}{$\begin{array}{c}\text { Oil percentage } \\
(\%)\end{array}$} & \multicolumn{2}{|c|}{$\begin{array}{l}\text { Oil yield } \\
\left(\mathrm{kg} \mathrm{ha}^{-1}\right)\end{array}$} \\
\hline & 2015 & 2016 & 2015 & 2016 & 2015 & 2016 \\
\hline \multicolumn{7}{|l|}{ Irrigation (I) } \\
\hline $\mathrm{I}_{1}$ & 1030.4 & 1136.3 & 48.35 & 50.25 & 504.3 & 578.51 \\
\hline $\mathrm{I}_{2}$ & 632.7 & 734.2 & 42.93 & 42.81 & 275.8 & 316.50 \\
\hline $\mathrm{I}_{3}$ & 483.7 & 493.7 & 37.18 & 40.05 & 181.6 & 199.00 \\
\hline St D $( \pm)$ & 168.1 & 147.3 & 3.68 & 2.97 & 94.24 & 89.19 \\
\hline $\operatorname{LSD}(P=0.05)$ & 79.2 & 17.15 & 2.39 & 2.87 & 35.19 & 32.68 \\
\hline \multicolumn{7}{|l|}{ Nano-Mg } \\
\hline Control & 648.7 & 699.67 & 42.35 & 42.82 & 287.2 & 309.0 \\
\hline Application & 782.4 & 876.5 & 43.29 & 45.92 & 353.8 & 420.3 \\
\hline St D $( \pm)$ & 281.0 & 292.2 & 5.92 & 5.03 & 165.6 & 175.8 \\
\hline $\operatorname{LSD}(P=0.05)$ & 26.51 & 14.71 & 0.83 & 0.74 & 14.05 & 10.44 \\
\hline \multicolumn{7}{|l|}{ Chitosan (CH) } \\
\hline $\mathrm{CH} 1$ & 571.5 & 668.0 & 39.71 & 42.36 & 235.4 & 294.6 \\
\hline $\mathrm{CH} 2$ & 710.1 & 791.4 & 43.12 & 44.48 & 317.5 & 365.4 \\
\hline $\mathrm{CH} 3$ & 865.1 & 904.8 & 45.63 & 46.27 & 408.7 & 433.9 \\
\hline St D ( $( \pm)$ & 262.3 & 294.3 & 5.43 & 5.08 & 151.8 & 179.2 \\
\hline $\operatorname{LSD}(P=0.05)$ & 32.47 & 18.02 & 1.02 & 0.91 & 17.2 & 12.79 \\
\hline \multicolumn{7}{|l|}{ Cultivar (C) } \\
\hline 'Oltan' (C1) & 681.7 & 748.4 & 42.09 & 43.82 & 298.2 & 341.2 \\
\hline 'Dashtestan-2' (C2) & 749.4 & 827.7 & 43.59 & 44.92 & 342.97 & 388.0 \\
\hline St D $( \pm)$ & 287.0 & 307.7 & 5.85 & 5.27 & 167.3 & 187.2 \\
\hline $\operatorname{LSD}(P=0.05)$ & 26.51 & 14.71 & 0.83 & 0.74 & 14.05 & 10.44 \\
\hline \multicolumn{7}{|l|}{ Interaction effect } \\
\hline $\mathrm{I} \times \mathrm{Mg}$ & $* *$ & $* *$ & $* *$ & $* *$ & $* *$ & $* *$ \\
\hline $\mathrm{I} \times \mathrm{CH}$ & $* *$ & $* *$ & $*$ & NS & $* *$ & $* *$ \\
\hline $\mathrm{I} \times \mathrm{C}$ & $* *$ & $* *$ & $* *$ & NS & $* *$ & $* *$ \\
\hline $\mathrm{Mg} \times \mathrm{CH}$ & $\mathrm{NS}$ & $* *$ & $\mathrm{NS}$ & $\mathrm{NS}$ & NS & $* *$ \\
\hline $\mathrm{Mg} \times \mathrm{C}$ & NS & NS & $*$ & NS & NS & NS \\
\hline $\mathrm{CH} \times \mathrm{C}$ & NS & NS & NS & NS & NS & NS \\
\hline $\mathrm{I} \times \mathrm{Mg} \times \mathrm{CH}$ & NS & NS & NS & NS & NS & $*$ \\
\hline $\mathrm{I} \times \mathrm{Mg} \times \mathrm{C}$ & $*$ & NS & NS & NS & $*$ & NS \\
\hline $\mathrm{I} \times \mathrm{CH} \times \mathrm{C}$ & NS & NS & NS & NS & NS & NS \\
\hline $\mathrm{Mg} \times \mathrm{CH} \times \mathrm{C}$ & NS & NS & NS & NS & NS & NS \\
\hline $\mathrm{I} \times \mathrm{Mg} \times \mathrm{CH} \times \mathrm{C}$ & NS & NS & NS & NS & NS & NS \\
\hline
\end{tabular}

LSD: least significant difference; NS: non-significant, ${ }^{*}$ and ${ }^{* *}$ significant 5 and $1 \%$ probably levels.

I1: normal irrigation; I2: irrigation cut-off in seed ripening (75 $\mathrm{BBCH}$ stage); I3: irrigation cut-off in flowering (65 $\mathrm{BBCH}$ stage); $\mathrm{CH} 1$ : non-application of chitosan; $\mathrm{CH} 2: 4.6 \mathrm{~g} \mathrm{~L}^{-1}$; $\mathrm{CH} 3: 6.4 \mathrm{~g} \mathrm{~L}^{-1}$;

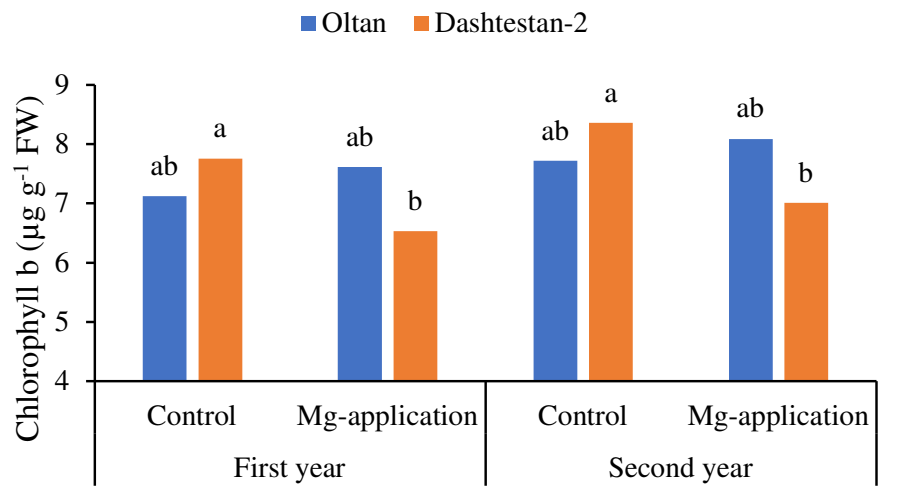

Figure 6. Chlorophyll b content affected by different sesame cultivars and nano-Mg chelate treatments, columns (for each year) with different letters are significantly different at $P=0.05$, using LSD test 


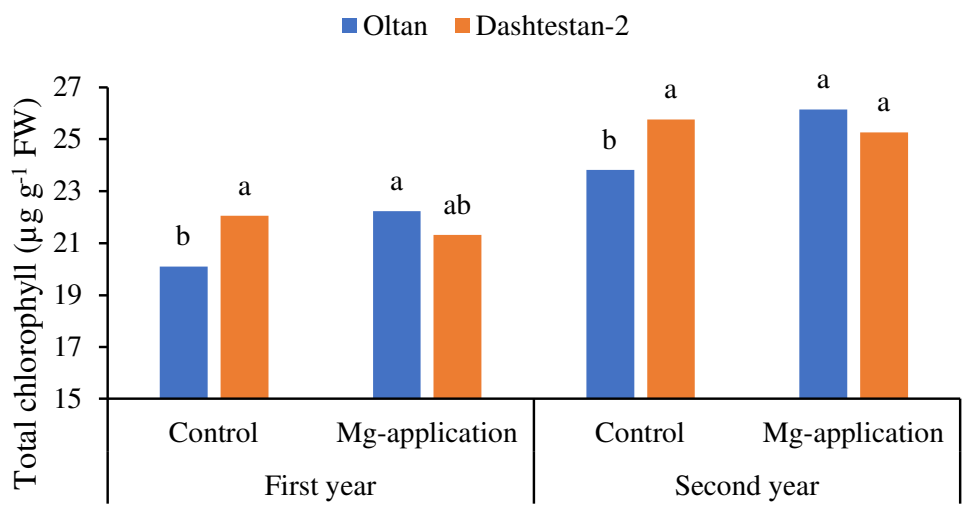

Figure 7. Total chlorophyll content affected by different sesame cultivars and nano-Mg chelate treatments, columns (for each year) with different letters are significantly different at $P=0.05$, using LSD test

\section{Discussion}

In the present study, a set of properties related to sesame medicinal plant including seed yield, oil content, photosynthetic pigments, antioxidant enzyme activities were determined by limited irrigation regimes and application of chitosan and magnesium-nano fertilizers. The results of ANOVA indicated that the effect of limited irrigation regimes and the application of chitosan and Mg nano-chelate on physiological traits such as free proline content, total sugars, CAT, POD, and APX activities, as well as on photosynthetic pigments such as chlorophyll a, b, and total, seed yield, and oil percentage and yield were significant. In addition, a significant difference was reported between the two cultivars. The superior cultivar in both years was related to 'Dashtestan-2', which resulted in creating higher seed yield, oil percentage, and yield, compared to 'Oltan' cultivar under stress condition. Further, 'Oltan' cultivar had a more positive response to the application of magnesium fertilizer than photosensitive pigments. Furthermore, 'Oltan' had a more positive reaction to the application of magnesium fertilizer, compared to the 'Dashtestan-2' cultivar in term of photosynthetic pigments.

In addition, increased levels of limited irrigation enhanced the rate of free proline significantly in both years. On the other hand, free proline content in the second year was higher than that of the first year. The increased production of free proline under water-limited stress is considered as the most sensitive osmotic responses of plants (Omidi et al., 2018). Further, water-limited stress increased the production of free proline content and the total soluble carbohydrates, and decreased plant growth, water-related properties, and carotenoids, and chlorophyll concentrations. Furthermore, proline improved plant water properties by adjusting osmoregulation because the cultivars ('Dashtestan-2') with higher proline rate had higher growth and yield (Omidi et al., 2018).

Likewise, the results of the present study indicated that the rate of proline, sugars, and CAT, POD, and APX activities increased under irrigation up to flowering $\left(\mathrm{I}_{3}\right)$, compared to the amount in the control treatment $\left(I_{1}\right)$. The results are consistent with those of other studies which indicated that the production of antioxidant enzymes and phenolic compounds increases under water stress condition, which is a mechanism used by plants to avoid the unfavourable effects of water stress (Varela et al., 2016). Additionally, the rate of free proline and protein contents, as well as the activity of antioxidants including superoxide dismutase and APX, increased in drought-stressed plants.

The results in the present study indicated that no significant difference was observed between control $\left(\mathrm{I}_{1}\right)$ and mild stress $\left(\mathrm{I}_{2}\right)$ conditions in the rate of chlorophyll $\mathrm{a}$, b, and the total content. However, the values of 
the traits decreased under severe stress $\left(\mathrm{I}_{3}\right)$. In addition, the reduction in chlorophyll $\mathrm{a}, \mathrm{b}$, and the total contents was reported in sunflower cultivars under severe water stress conditions.

However, a reduction occurred in seed yield, oil percentage, and yield of sesame seed under water-limited stress, while the use of $\mathrm{Mg}$ nano-chelate resulted in increasing the value of traits compared to the nonapplication of treatment in both years. The decrease in oil content due to water stress can be related to the disturbance in the metabolic processes of seeds and damage to the transfer of assimilat to seeds. The results are in line with those in some previous studies (Morteza et al., 2013). In general, Mg plays an important role in both photosynthesis and protein-synthesis in leaves. Latent $\mathrm{Mg}$ deficiencies are common, and $\mathrm{Mg}$ addition indicated an improved yield (Xiao et al., 2018). Mg deficiency in the plant reduced the amount of chlorophyll and resulted in decreasing the growth of the plant. In another study, the use of $\mathrm{Mg}$ increased seed yield of sesame significantly. In the flowering stages, an increase occurs in the plant need for the nutrient. Thus, the availability of sufficient nutrients results in increasing seed yield and oil content. Some believe that the oil content is controlled by genetic factors, but the availability of essential elements in the critical stage of plant life can affect the rate of photosynthesis and production of plant metabolites, and ultimately help to accumulate oil and enhanced growth (Nikolova and Popp, 2013; Kaluzewicz et al., 2017).

In addition, the results indicated that applying $6.4 \mathrm{~g} \mathrm{~L}^{-1}$ increases seed yield and oil content in chitosan treatment in both years. Researchers reported that the application of chitosan on soybean increases the rate of yield significantly, compared to the non-application case. The use of chitosan foliar plays a role in reducing the diameter of the stoma to prevent from depleting cell water, which leads to an increase in the biomass and final yield. Further, chitosan contributes to an increase in photosynthesis by enhancing the chlorophyll content, which can be regarded as one of the reasons for increasing seed yield in the present study (Zeng et al., 2012). Furthermore, chitosan may be facilitated by controlling the wastewater pathways and increasing root area levels in order to increase cell bioactivity and the oil yield.

Finally, the superiority of 'Dashtestan-2' is more than genetic variation, compared to 'Oltan' cultivar. Based on the results, 'Oltan' cultivar has a high reactivity to the application of Mg nano-chelate and chitosan. The seed yield and oil content during the second year were higher than the amounts in the first year, due to the favourable climate conditions in terms of temperature and precipitation in the second year.

\section{Conclusions}

The results of the present study indicate that the yield and physiological properties including proline content, total sugars, activity of antioxidant enzymes such as CAT, POD, and APX, photosynthetic pigments, seed yield, and oil content of different cultivars in sesame, as a medical plant, may be differently affected by foliar application of nano-Mg and chitosan and water-limited stress. Further, the plant uses some avoiding and tolerating mechanisms such as an increase in proline, sugars, activity of CAT, POD, and APX enzymes in order to survive under severe water stress. Further, such tolerance is the result of some physiological and biochemical activities in the plant among which the increased production of proline, sugars, activity of CAT, POD, and APX enzymes are highlighted as the most important ones, which are related to both medicinal and defensive values. Additionally, 'Dashtestan-2' cultivar had more tolerant cultivar under water stress. It is worth noting that the foliar application of nano- $\mathrm{Mg}$ and chitosan fertilizers leads to the increased production of the total chlorophyll, seed yield, and oil content. Furthermore, the co-application of nano-Mg and $\mathrm{CH} 2\left(4.6 \mathrm{~g} \mathrm{~L}^{-1}\right.$ chitosan) increased the production of proline and sugars significantly while decreased the activity of CAT, POD, and APX enzymes, which may be regarded as one of the physiological reasons of sesame cultivars for the water-limited stress condition. Thus, nano-Mg and chitosan foliar application are recommended in sesame fields, especially under water-limited supply condition. Future research can be conducted on evaluating the foliar application of nano-Mg and chitosan on oil quality of sesame under water-limited stress, which is more efficient in the production of oilseed crops. 


\section{Authors' Contributions}

All authors read and approved the final manuscript.

\section{Acknowledgements}

This research received no specific grant from any funding agency in the public, commercial, or not-forprofit sectors.

\section{Conflict of Interests}

The authors declare that there are no conflicts of interest related to this article.

\section{References}

Anaya F, Fghire R, Wahbi S, Loutfi K (2018). Influence of salicylic acid on seed germination of Vicia faba L. under salt stress. Journal of the Saudi Society of Agricultural Science 17(1):1-8. https://doi.org/10.1016/j.jssas.2015.10.002

Asda K (1992). Ascorbate peroxidase-a hydrogen peroxide-scavenging enzyme in plants. Physiologia Plantarum 85(2):235-241. https://doi.org/10.1111/j.1399-3054.1992.tb04728.x

Bates LS, Waldern RP, Teave ID (1973). Rapid determination of free proline for water stress studies. Plant and Soil 39(1):205-207.

Blasco B, Graham NS, Broadley MR (2015). Antioxidant response and carboxylate metabolism in Brassica rapa exposed to different external $\mathrm{Zn}, \mathrm{Ca}$, and $\mathrm{Mg}$ supply. Journal of Plant Physiology 176:16-24. https://doi.org/10.1016/j.jplph.2014.07.029

Ceppi M, Oukarroum G, Cicek A, Strasser N, Schansker G (2012). The IP amplitude of the fluorescence rise OJIP is sensitive to changes in the photosystem I content of leaves: a study on plants exposed to magnesium and sulfate deficiencies, drought stress and salt stress. Physiologia Plantarum 144(3):277-288. https://doi.org/10.1111/j.1399-3054.2011.01549.X

Chance B, Maehly AC (1955). Assay of catalase and peroxidase. Methods in Enzymology 2:764-775.

Chou TS, Chao YY, Huang WD, Hong CY, Kao CH (2010). Effect of magnesium deficiency on antioxidant status and cadmium toxicity in rice seedlings. Journal of Plant Physiology 168(10):1021-1030. https://doi.org/10.1016/j.jplph.2010.12.004

Farouk S, ad Amany AR (2012). Improving growth and yield of cowpea by foliar application of chitosan under water stress. Egyptian Journal of Biology 14(1):14-26. https://dx.doi.org/10.4314/ejb.v14i1.2

Kaluzewicz A, Krzesinski W, Spizewski T, Zaworska A (2017). Effect of biostimulants on several physiological characteristics and chlorophyll content in broccoli under drought stress and re-watering. Notulae Botanicae Horti Agrobotanici Cluj-Napoca 45(1):197-202. https://doi.org/10.15835/nbha45110529

Lichtenthaler HK (1987). Chlorophylls and carotenoids. Pigments of photosynthetic membranes. Methods in Enzymology 148:350-382. https://doi.org/10.1016/0076-6879(87)48036-1

Mafakheri A, Siosemardeh AF, Bahramnejad B, Struik PC, Sohrabi Y (2010). Effect of drought stress on yield, proline and chlorophyll contents in three chickpea cultivars. Australian Journal of Crop Science 8:580.

Morris DL (1948). Quantitative determination of carbohydrates with dreywood's anthrone reagent. Science 107:254255. https://doi.org/10.1126/science.107.2775.254

Morteza E, Moaveni P, Farahani HA, Kiyani M (2013). Study of photosynthetic pigments changes of maize (Zea mays L.) under nano $\mathrm{TiO}_{2}$ spraying at various growth stages. Springer Plus 2(1):247. https://doi.org/10.1186/21931801-2-247

Nikolova M, Popp T (2013). The effect of different potash and magnesium fertilizers and timing of application on yield and oil content of oilseed rape. International Potash Institute E-IFC 34:1-29. 
Omidi H, Shams H, Sahandi MS, Rajabian T, Miransari M (2018). Balangu (Lallemantia sp.) growth and physiology under field drought conditions affecting plant medicinal content. Plant Physiology and Biochemistry 130:641646. https://doi.org/10.1016/j.plaphy.2018.08.014

Pongprayoon W, Roytrakul S, Pichayangkura R, Chadchawan S (2013.) The role of hydrogen peroxide in chitosaninduced resistance to osmotic stress in rice (Oryza sativa L.). Plant Growth Regulation 70(2):159-173. https://doi.org/10.1007/s10725-013-9789-4

Roul B, Mishra BK, Prusty N (2017) Natural effect of micronutrient on growth and growth parameter of sesame oilseed crop. Pharmacognosy and Phytochemistry 6:1926-1928.

Senbayram M, Gransee A, Wahle V, Thiel H (2015). Role of magnesium fertilizers in agriculture. Plant-soil continuum. Crop and Pasture Science 66(12):1219-1229. https://doi.org/10.1071/CP15104

Sheikha SAAK, Al-Malki FM (2011). Growth and chlorophyll responses of bean plants to the chitosan application. European Journal of Scientific Research 50(1):124-134.

Solgi M (2018). The application of new environmentally friendly compounds on postharvest characteristics of cut carnation (Dianthus caryophyllus L.). Brazilian Journal of Botany 41(3):515-522.

Sultana S, Islam M, Khatun MA, Hassain MA, Huque R (2017). Effect of foliar application of oligo-chitosan on growth, yield and quality of tomato and eggplant. Asian Journal of Agricultural Research 11(2):36-42. https://doi.org/10.3923/ajar.2017.36.42

Taieb Baiazidi Aghdam M, Mohammadi H, Ghorbanpour M (2016). Effects of nanoparticulate anatase titanium dioxide on physiological and biochemical performance of Linum usitatissimum (Linaceae) under well-watered and drought stress conditions. Brazilian Journal of Botany 39(1):139-146. https://doi.org/10.1007\%2Fs40415015-0227- $x$

Varela MC, Arslan I, Reginato MA, Cenzano AM, Luna MV (2016). Phenolic compounds as indicators of drought resistance in shrubs from Patagonian shrublands (Argentina). Plant Physiology and Biochemistry 104:81-91. https://doi.org/10.1016/j.plaphy.2016.03.014

Wendel A (1981). Glutathione peroxidase. Methods in Enzymology 77:325-333. https://doi.org/10.1016/S00766879(81)77046-0

Xiao S, Jihui C, Andrea R, Xue X, Yingjun Z, Tongtong P (2018). Effects of magnesium fertilizer on forage crude protein content depend upon available soil nitrogen. Journal of Agricultural and Food Chemistry 66(8):1743-1750. https://doi.org/10.1021/acs.jafc.7b04028

Yanni Y, Zidan M, Dazzo F, Rizk R, Mehesen A, Abdelfattah F, Elsadany A (2016). Enhanced symbiotic performance and productivity of drought-stressed common bean after inoculation with tolerant native rhizobia in extensive fields. Agriculture. Agriculture, Ecosystems and Environment 232:119-128. https://doi.org/10.1016/j.agee.2016.07.006

Yin H, Ba XF, Du YG (2008). The primary study of oligo chitosan inducing resistance to Sclerotinia scleraotiorum on $B$. napus. Journal of Biotechnology 136(4):600-601.

Zeng D, Luo X, Tu R (2012). Application of bioactive coatings based on chitosan for soybean seed protection. Journal of Carbohydrate Chemistry 12:1-5. https://doi.org/10.1155/2012/104565

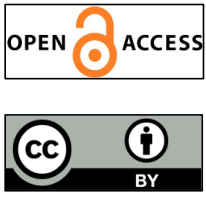

The journal offers free, immediate, and unrestricted access to peer-reviewed research and scholarly work. Users are allowed to read, download, copy, distribute, print, search, or link to the full texts of the articles, or use them for any other lawful purpose, without asking prior permission from the publisher or the author.

License - Articles published in Notulae Botanicae Horti Agrobotanici Cluj-Napoca are Open-Access, distributed under the terms and conditions of the Creative Commons Attribution (CC BY 4.0) License. (c) Articles by the authors; UASVM, Cluj-Napoca, Romania. The journal allows the author(s) to hold the copyright/to retain publishing rights without restriction. 